\title{
Review on Bacterial Blight of Rice Caused by Xanthomonas oryzae pv. oryzae: Different Management Approaches and Role of Pseudomonas fluorescens As A Potential Biocontrol Agent
}

\author{
Pranamika Sharma $^{1 *}$, L.C. Bora ${ }^{1}$, K.C. Puzari ${ }^{1}$, A.M. Baruah ${ }^{2}$, R. Baruah ${ }^{3}$, \\ K. Talukdar ${ }^{1}$, L. Kataky ${ }^{1}$ and A. Phukan ${ }^{3}$ \\ ${ }^{1}$ Department of Plant Pathology, Assam Agricultural University, Jorhat-13, India \\ ${ }^{2}$ Department of Biochemistry and Agricultural Chemistry, Assam Agricultural University, \\ Jorhat-13, India \\ ${ }^{3}$ Department of Soil Science, Assam Agricultural University, Jorhat-13, India \\ *Corresponding author
}

\begin{tabular}{|c|c|}
\hline & A B S T R A C T \\
\hline $\begin{array}{l}\text { K e y w o r d s } \\
\text { Bacterial blight, } P \text {. } \\
\text { fluorescens, } \\
\text { Aggressiveness, } \\
\text { Micronutrient, Zinc. }\end{array}$ & \multirow{3}{*}{$\begin{array}{l}\text { Bacterial blight is a destructive disease of rice causes } 20-50 \% \text { yield losses in } \\
\text { conducive conditions. In this paper a review on the occurrence and spread of } \\
\text { the disease, about the pathogen, its races and strains, its survival, mode of } \\
\text { infection and transmission, different management approaches and potential } \\
\text { role of } P \text {. fluorescens in suppression of the pathogen has been carried out. } \\
\text { From the laboratory and field assays it is evidenced that } P \text {. fluorescens is an } \\
\text { effective bioagent against } X \text {. oryzae pv. oryzae. The integration of } \\
\text { micronutrient with } P \text {. fluorescens has also been view in this chapter to find out } \\
\text { the role of micronutrients in enhancing the aggressiveness of bioagent. }\end{array}$} \\
\hline Article Info & \\
\hline $\begin{array}{l}\text { Accepted: } \\
\text { 18 February } 2017 \\
\text { Available Online: } \\
10 \text { March } 2017\end{array}$ & \\
\hline
\end{tabular}

\section{Introduction}

Rice (Oryza sativa L.) is one of the most important food crops in the world, feeding about half of humanity with a worldwide production of 470.63 million metric tons in an area of 157.46 million hectares with productivity of 4.46 metric tons per hectare (Annonymous, 2016). Among the rice growing countries in the world, India has the largest area under rice crop and ranks second in production next to China. In India, rice is an important part of the diet of its people and cultivation of rice is the main occupation of those engaged in agriculture. The crop is regarded as the second major cereal crop of India after wheat with a production of 103.00 million metric tons in an area of 42.75 million hectares with a productivity 3.61 metric tons per hectare (Annonymous, 2016), which share 43 percent of total food grain production and 46 percent of total cereal production in the country. Rice is highly vulnerable at all stages of growth to different pathogens that affect the quality and quantity of its yield. Among several diseases caused by bacterial, fungal and viral pathogens that devastate rice field all over the world, bacterial blight (BB) 
(Xanthomonas oryzae pv. oryzae), blast (Magnaporthe grisea), sheath blight (Rhizoctonia solani), sheath rot (Sarocladium oryzae), and tungro viruses are the most important. BB caused by $X$. oryzae pv. oryzae is one of the most important and oldest known diseases of rice. The use of plant growth promoting rhizobacteria (PGPR) has been widely adapted in the field of agriculture as it offers an attractive way to improve crop growth and development, replacing or supplementing fertilizers and pesticides. In terms of environmental health, biocontrol agents are considered to be environmentally sound alternative to chemical protections. To date, a number of biocontrol agents have been registered and are available on the market as commercial products, including strains belonging to the bacterial genera Pseudomonas, Streptomyces and Bacillus, and fungal genera such as Trichoderma and Gliocladium. The inconsistency in efficacy of the biocontrol agents has been a matter of concern and must be reduced in order to increase the effectiveness against diseases and to create a reliable alternative in place of chemical control. Recent research in our laboratory has showed that use of micronutrient along with the bioagent is an effective management strategy for management of this devastating disease (Unpublished data). The pertinent literature regarding the identification of factors that together with the biocontrol agents can achieve a synergetic effect and stimulate the antagonistic effect of biocontrol agents against diseases have been reviewed in this chapter under the following heads.

\section{The bacterial blight (BB) disease of rice}

Bacterial blight caused by Xanthomonas oryzae pv. oryzae is one of the most important and oldest known diseases of rice. The disease was first observed by the farmers of Japan in 1884 (Tagami and Mizukami, 1962).
Crop losses of 10-20 per cent in moderate conditions or severe losses of up to 50 per cent in highly conducive conditions have been recorded in several Asian and Southeast Asian countries (Ou, 1985). Globally, BB incidence has been reported from different parts of Asia, northern Australia, Africa, and the United States. In India, BB disease has been observed in most important rice-growing states like Andhra Pradesh, Bihar, Haryana, Kerala, Orissa, Punjab and Uttar Pradesh.

$\mathrm{BB}$ is a vascular disease resulting in a systemic infection (Mew, 1987) that produces tannish-grey to white lesions along the veins. Symptoms are observed at the tillering stage, disease incidence increases with plant growth, peaking at the flowering stage (Mew, 1992). Kresek is the more destructive manifestation of the disease, wherein the leaves of the entire plant turn pale yellow and wilt during the seedling to the early tillering stage, resulting in a partial or total crop failure. Plants less than 21 days old are the most susceptible and temperatures between 28 and $34^{\circ} \mathrm{C}$ favour kresek development (Mew et al., 1979 and Mizukami and Wakimoto, 1969). BB is characteristic of yellow lesions with wavy margins on leaf blades that may extend to the sheath. The occurrence of bacterial ooze from infected leaves has been observed in warm and humid climates, which contributes to the spread of this disease. While damage is extensive when kresek precedes $\mathrm{BB}$, post flowering infections have very little effect on grain yield.

$\mathrm{BB}$ is favoured by warm temperatures (25 to $30^{\circ} \mathrm{C}$ ), high humidity, rain, and deep water. The disease is more prevalent in wetland areas where these conditions often occur. Winds severe enough to cause wounds and excess nitrogen also favour the disease. The severity of the disease is in part dependent on the virulence of the bacterial isolates present. Bacterial blight is severe in susceptible rice 
varieties under high nitrogen fertilization (Annonymous, 2004; 2010). The bacterium can be disseminated by irrigation water, by splashing or windblown rain, by plant-toplant contact, by trimming tools used in transplanting, and by handling plants during transplanting (Mew, 1992).

The pathogen Xanthomonas oryzae pv. oryzae (Xoo)

In 1908, Takaishi found bacterial masses in dew drops of rice leaves but he did not name the organism (Mizukami and Wakimoto, 1969). Bokura in 1911 isolated a bacterium, and after a study of its morphology and physiology, the bacterium was named Bacillus oryzae (Mizukami and Wakimoto, 1969). Ishiyama, 1922 studied the disease further and renamed the bacterium Pseudomonas oryzae according to Migula's system. It was later named as Bacterium oryzae and subsequently as Xanthomonas oryzae. According to the revision of the International Code of Nomenclature of Bacteria (ICNB) the committee on taxonomy of phytopathogenic bacteria of the International Society of Plant Pathology adopted the name Xanthomonas campestris pv. oryzae Dye (Mew et al., 1993 and Ishiyama, 1922). In 1990, the pathogen was elevated to a species status and was named Xanthomonas oryzae pv. oryzae (Swings et al., 1990).

The pathogen is a yellow, slime-producing, motile, gram negative rod with a polar flagellum and enters the host normally through wounds or natural openings. It reaches the vascular tissue, particularly the xylem, from where it multiplies and spreads throughout the plant. The bacterium is systemic in the xylem of the rice host. A type III protein secretion system exists in this bacterium to directly inject virulence factors into the host (Furutani et al., 2009).

\section{Races and strains of Xoo}

Over 30 races of Xoo are reported to occur. The different races, however, have not been clearly defined with specific reactions being assigned to each rice variety/cultivar (NinoLiu et al., 2006 and Annonymous, 2007). A race is a subgroup or biotype within a species, distinguished from other races by virulence not by morphology.

Morphological, physiological and biochemical characters do not reveal differences to delineate pathogenicity/virulence grouping of Indian isolates (Reddy and Reddy, 1990). Five virulence groups of the $\mathrm{BB}$ pathogen have been identified based on infection responses elicited on rice lines containing combinations of 2, 3 and 4 major $R$ genes. However, the difference in virulence was not sufficient in magnitude for classification into pathogenic races (Adhikari et al., 1999). Classical pathotyping which uses a set of differential rice cultivars is laborious and time consuming. Therefore, a serological classification of Indian strains of the rice BB pathogen was carried out using monoclonal antibodies (Mabs) (Gnanamanickam et al., 1993). A panel of 6 Mabs (specific to Xoo) was reacted to 70 Indian strains of the pathogen and six serogroups were identified. Serogroup I had 51 strains and the remaining 19 strains formed 4 new serogroups IIa, IIb, V and VII which have not been known among the global populations of the BB pathogen (Benedict et al., 1989). These results suggest that pathotypes may not relate to the serological diversity observed in the pathogen. The use of RFLP as a reliable tool for understanding the population biology and structure of Xoo has been well documented (Adhikari et al., 1995; Ardales et al., 1996; Leach et al., 1990; Leach et al., 1992; Leach et al., 1995; Nelson et al., 1994). A repetitive DNA sequence, pJEL101 isolated from the 
genome of Xoo was used to assess its genetic variability and population structure (Ardales et al., 1996; Leach et al., 1990; Nelson et al., 1994). Also, the repetitive elements IS1113 and IS1112 hybridized with large number of bands and served as informative probes (Nelson et al., 1994). One of the avirulence genes, avrXa10, has also been used as a probe to differentiate Xoo strains from the Philippines (Kelemu and Leach, 1990; Hopkins et al., 1992). The probe hybridized with 9 to 23 different sized DNA fragments in the genome of a strain. In RFLP analysis, 9 haplotypes were detected by probe pJEL101 and 5 haplotypes were detected by avrXalO probe among the Indian strains. The study also identified 5 distinct genetic clusters from among the Asian collection of strains from China, India, Indonesia, Korea, Malaysia, Nepal and the Philippines. The Indian strains formed cluster No. 5 along with Nepalese, Malaysian and Indonesian strains (Ardales et $a l .$, 1996). Whether the haplotypes identified from such fingerprints correspond to the pathotypes distinguished through virulence analysis remains to be established (Nelson et al., 1994). However, in a recent attempt to fingerprint the pathogen population in India using the avrXalO and IS1112 probes, the strains appear to be closely related to each other, belonging to a single lineage. Pathotyping analysis of these strains revealed that the strains in this lineage belong to the pathotype 1b (Yashitola et al., 1997).

\section{Survival, mode of infection and transmission of the pathogen}

Xoo survives primarily in rice stubble and on weed hosts, notably Leersia oryzoides, Zizania latifolia Leptocholoa chinensis, L. panicea and Cyperus rotundis. In Australia, the bacterium is known to survive in wild Oryza species (O. rufipogon and $O$. australiensis). Xoo can also survive for short periods on infected seed and in soil, but these have not been demonstrated to be important sources of inoculum. In tropical areas, the bacterium may also survive in irrigation water (Mew, 1992).

Successful infection involves the movement of the bacterium towards the host, contact between the two, penetration of the host and proliferation of the bacterium inside the host immediately following entry. The BB pathogen mainly enters through hydathodes as suggested by electron microscopic studies (Horino, 1984 and Mew et al., 1984). Wounds on rice leaves are also favourable avenues for entry of the pathogen. The infection seems more successful in the case of entry of the pathogen through wound sites than natural openings. However, new wounds are more conducive to infection than old wounds. Also, Kiryu et al., (1954) demonstrated that abundant inoculum results in higher percentage of infection. Xoo enters the rice leaf typically through the hydathodes at the leaf tip and leaf margin. Bacterial cells on the leaf surface may become suspended in guttation fluid as it exudes at night and then enter the plant by swimming, or passively as the fluid is withdrawn into the leaf in the morning. Bacteria multiply in the intercellular spaces of the underlying epithelial cells. It then enters and spreads into the plant through the xylem. Xoo may also gain access to the xylem through wounds or openings caused by emerging roots at the base of the leaf sheath. Within the xylem, Xoo presumably interacts with the xylem parenchyma cells. The pathogen moves vertically through the leaf via the primary veins. It may progress laterally through commissural veins. Within a few days, bacterial cells and EPS (extracellular polysaccharide) fill the xylem vessels and ooze out from hydathodes, forming beads or strands of exudate on the leaf surface, a characteristic sign of the disease and a source of secondary inoculum (Nino-Liu et al., 2006). 
The 'kresek' syndrome is generally associated with seedling infection that occurs through wounds made during transplanting operations. The roots of seedlings are often damaged when they are removed from the nurseries, and in many areas, the tops of the leaves are clipped off before transplanting. The severity of kresek is dependent on the time of infection; the earlier seedlings are infected, the more severe is the syndrome. Irrigation water is considered to contribute to the spread of this disease over large areas of cultivated land, as it carries the bacterial ooze that drop into rice field water. However, the role of water as a primary mode of transmission has been disputed as the pathogen survives only for 15 days in field water (Tagami et al., 1963; Premalatha Dath, and Devadath, 1983). The BB pathogen is also seed-borne, although the extent to which it is transmitted through the seed has been questioned (Unnamalai et al., 1988). Moreover, the seed-borne transmission of infection either in the nursery or in the field has not been positively proved (Tagami et al., 1963; Murty and Devadath, 1984). A PCR assay for amplification of Xoo DNA using primers derived from a repetitive mobile element IS1113 could not detect the pathogen DNA from seeds collected from infected plants (Gnanamanickam et al., 1995).

\section{Pathogenicity and method of inoculation}

Leaf clipping and spray inoculation methods are available for inoculations (Kauffman et al., 1973; Cottyn et al., 1994; Annonymous, 2007). Nino-Liu et al., (2005) inoculated plants by dipping them in bacterial mixture and incubating in a growth chamber. Symptoms developed a 6-day period.

\section{Management of bacterial blight of rice}

Attempts to control BB through chemicals like Bordeaux mixture with or without sugar, copper-soap mixture and copper-mercury fungicides were made (Sulaiman and Ahmed, 1965). Spraying copper oxychloride and streptomycin solution at short intervals was recommended to control this disease (Seki and Mizukami, 1956). Chlorinating irrigation water with stable bleaching powder was also reported to be effective in minimizing the disease (Chand et al., 1979). Synthetic organic bactericides such as nickel dimethyl dithiocarbamate, dithianone, phenazine and phenazine Noxide were also recommended (Fukunaga, 1966). Spraying techlofthalam was more useful than soil application and it translocated readily and inhibited bacterial multiplication in rice plants (Nakagami et al., 1980a; Nakagami et al., 1980b; Takahi, 1985). Seed treatment with hot water at $57^{\circ} \mathrm{C}$ for $10 \mathrm{~min}$ or disinfecting with mercury compounds was suggested earlier to eradicate seed-borne inoculums (Tagami et al., 1963).

In rice, the genetics of resistance to several pathogens has been well characterized. Resistance of rice plants towards Xoo at different growth stages varies according to host genotypes as seedling resistance (at seedling stage) and adult plant resistance (at adult stage but susceptible at seedling stage) (Mew, 1987).

Genetic transformation of rice offers numerous important opportunities for the improvement of existing elite varieties and development of new cultivars. A major advantage of genetic engineering is that it allows breeders to rapidly develop new varieties by the introduction of cloned genes into commercial varieties. Zhang et al., (1998) have reported the regeneration of transgenic fertile plants from four Elite indica varieties in group 1, viz. IR64, IR72, Minghui63 and BG90-2 carrying bacterial blight resistance gene $\mathrm{Xa21}$. This was found to impart significantly improved resistance to the $\mathrm{BB}$ pathogen and this resistance was shown to be stably inherited in subsequent 
generations. Wang et al., (1996) transformed japonica rice variety T309 with cloned Xa21, and its resistance spectrum was similar to that of the donor line IRBB21. Tu et al., (1998) reported that the transformation of Elite indica rice variety IR72 with $\mathrm{Xa21}$ gene confers resistance to the BB pathogen and this resistance was shown to be stably inherited in subsequent generations.

\section{Biological management of bacterial blight of rice}

Biological control of plant pathogens by antagonistic microorganisms is known to be a cheap, effective and eco-friendly method for the management of crop diseases (Cook and Baker, 1983). The use of biological control agents as an alternative to fungicides has been increasing rapidly in the present day agriculture due to the deleterious effects of chemical pesticides. Members of the genus Pseudomonas and Trichoderma have long been known for their potential to reduce the plant disease caused by fungal and bacterial pathogens (Pant and Mukhopadhyay, 2001). The bacterial antagonists have the twin advantage of faster multiplication and higher rhizosphere competence.

Bacterial antagonists have been evaluated with various degrees of success for the suppression of rice diseases of fungal origin (Vasudevan et al., 2002). The ability of bacterial antagonist $P$. fluorescens strain 7-14, to suppress both blast and sheath blight of rice has been well established (Gnanamanickam and Mew, 1992; Chatterjee et al., 1996; Krishnamurthy and Gnanamanickam, 1998).

The use of biocontrol agents to bring about BB suppression remains to be explored in detail. However, use of antagonistic bacteria like Bacillus sp. for suppression of $\mathrm{BB}$ of rice has been documented (Vasudevan, 2002).

\section{Pseudomonas fluorescens as biocontrol agent}

Fluorescent Pseudomonads exhibit diverse mechanism of biocontrol which include antibiosis, cyanide production, siderophore production, competition for space and nutrient and induced systemic resistance. Unnamalai and Gnanamanickam (1984) reported that $P$. fluorescens could inhibit the growth of $X$. campestris pv. citri and correlated the antagonism to the production of siderophore. In vitro antibiosis of $P$. fluorescens strains towards the rice sheath rot pathogen $S$. oryzae was also demonstrated (Sakthivel and Gnanamanickam, 1987). P. fluorescens have been successfully used for biological control of several plant pathogens (Ramanathan et al., 2002). Pseudomonads produces a broad spectrum of antibiotics, including pyoluteorin (PLT), pyrrolnitrin (PRN) and 2,4diacetylphloroglucinol and also hydrogen cyanide and the siderophores namely pyochelin and pyoverdin (Stutz et al., 1986). Anuratha and Gnananmanickam (1990) also reported the production of antibiotics by $P$. fluorescens.

Besides enhancement of plant growth and yield through production of plant growth promoting substances such as auxin and gibbelellins (Dubeikovsky et al., 1993) fluorescent pseudomonads can also induce systemic resistance (ISR) by enhancement of plant defence mechanisms (Ramamoorthy and Samiyappan, 2001 and Zuhnder et al., 2000). Fluorescent pseudomonads activate ISR against various fungal, bacterial and viral diseases (Liu et al., 1995), insects (Zuhnder et al., 1997) and nematode pests (Sikora, 1998). ISR in plants can be associated with increase in activity of chitinase, $\beta$-1-3-glucanases, peroxidase and other pathogenesis related protein accumulation of phytoalexin, lignin, callose and hydroxyproline rich glycoproteins. ISR also involves the induction 
of lytic enzymes, phenolics and phenylalanine ammonia-lyase (PAL) (Meena et al., 2000). Manifestation of ISR is dependent on the combination of host plant and bacterial strain (Loon et al., 1998). Thus, fluorescent pseudomonads have emerged as the biggest and potentially the most promising group amongst the PGPRs, involved in biocontrol of diseases due to presence of all above mechanisms of pathogen suppression.

Fluorescent Pseudomonas is uniquely capable of synthesizing many of these antibiotics, not only to enhance its own fitness but also to help in the maintenance of soil health and bioprotection of crops from pathogens (Gaur et al., 2004). Presently, there are number of commercial isolates of Pseudomonas available in the market. However, the native isolates of certain biocontrol agents showed superiority over other isolates for the management of crop diseases (Dubey and Patel, 2001).

Velusamy et al., (2005) screened a subpopulation of 27 strains of plantassociated $P$. fluorescens which could produce DAPG and this compound inhibited the growth of the devastating rice bacterial blight pathogen Xoo in laboratory assays and suppressed rice bacterial blight up to 59-64 per cent in net-house and field experiments.

Jeyalakshmi et al., (2010) found that the combination of seed treatment, soil application and foliar spray with $P$. fluorescens give the minimum disease incidence of bacterial leaf blight with maximum yield in comparison with the chemical treatment and control.

Shyamala and Sivakumaar (2012) reported that $P$. fluorescens can suppress Pyricularia oryzae by exhibiting a variety of promising physical properties such as protease, IAA and siderophore production.
Noori and Saud (2012) isolated 20 strains of Pseudomonads from the rhizosphere of paddy, which were gram negative, oxidasepositive, rod shaped and all produced yellowish green pigment on King's B medium. When screened for their PGP activity, all the strains could produce siderophores, HCN and IAA, and could inhibit Xoo in the dual culture assay.

Meera and Balabaskar (2012) reported that thirty five isolates of $P$. fluorescens were found effective against $S$. oryzae. However, out of the thirty five isolates, seven isolates were found significantly superior to other isolates in inhibiting $S$. oryzae. A maximum inhibition 93.3 per cent was recorded by strain PF 013 and minimum of 68.2 per cent was recorded with the strain PF 03.

\section{Isolation of $\boldsymbol{P}$. fluorescens}

Klyuchnilov and Kozhevin (1990) in former USSR, found that the most numerous and active population of $P$. fluorescens were found in the exorhizosphere of potato. Hebbar et al., (1991) studied bacteria associated with sunflower leaves and roots that inhibited in vitro the growth of many fungal pathogens in France. The root-associated bacteria were identified as $P$. fluorescens which could be used as seed inoculum to improve plant growth. Thara and Gnanamanickam (1994) isolated 1757 isolates of bacterial antagonists and identified both fluorescent and non fluorescent groups. Tzeng et al., (1994) isolated a total of 151 strains of fluorescent pseudomonads from various crop at different localities in Taiwan. They also found most of the foliar fluorescent pseudomonad strains to be saprophytic.

Rangeshwaran and Prasad (2000) collected 300 isolates from different regions of Karnataka. Four isolates belonging to $P$. 
fluorescens viz., $\mathrm{PDBCAB}$ 2, $\mathrm{PDBCAB} 19$, PDBCAB 29, PDBCAB 30, were most prominent. Mabagala (1999) isolated naturally occurring epiphytic non-pathogenic bacteria from reproductive tissue of various bean genotypes grown in field. Among that one isolate was identified as $P$. fluorescens which was antagonistic to $X$. axonopodis pv. phaseoli in vitro.

\section{Screening and biochemical characterization of $\boldsymbol{P}$. fluorescens}

The characters involving basic screening of PGPR are nutrient acquisition such as $\mathrm{N}_{2}-$ fixation, P-solubilization and also growth hormone production and disease control activities. Therefore, the cultures isolated must fulfil any of these characters. In addition to this, it is also essential for characterization of isolated organism such as morphology, biochemical and molecular to authenticate strain variation within isolated cultures. The works carried out in this regard has been reviewed.

Ahmad et al., (2008) isolated 72 bacterial cultures from different cropped rhizosphere and screened them to find efficient strains. The cultures were characterized on the basis of hydrolysis of starch, lipid, chitin, biochemical characters like fermentation of different sugars etc. Further, these isolates were screened for their plant growth promoting traits like - IAA production, ammonia production, phosphate solubilization, Siderophore production and antifungal activities. The results showed that more than 80 per cent of isolates belonging to Azotobacter, Pseudomonas and Mesorhizobium. Solubilization of phosphate was commonly detected in the isolates of Bacillus (80\%) followed by Azotobacter (74.47\%), Pseudomonas (55.56\%) and Mesorhizobium (16.67\%). All test isolates could produce ammonia but none of the isolates hydrolyzed chitin. Siderophore production and antifungal activity of these isolates were exhibited. $\mathrm{HCN}$ production was more common trait of Pseudomonas and Bacillus. On the basis of multiple plant growth promoting activities, eleven bacterial isolates (seven Azotobacter, three Pseudomonas and one Bacillus) were evaluated.

Ammonia released by diazotrophs is one of the most important traits of PGPR's which benefits the crop (Kundu et al., 1987). Bacillus subtilis strain MA-2 and $P$. fluorescens strain MA-4 was efficient in ammonia production and significantly increased biomass of medicinal and aromatic plant such as Geranium (Mishra et al., 2012).

Proteolytic activity is one of the characters of many PGPR and differs among the cultures. Ellaiah et al., (2002) isolated 30 different bacteria producing protease from seven protein rich soil samples. Among these, nine categories showed good proteolytic activity, seven showed moderate, eight showed very poor and six categories showed negligible activity. Out of 220 phosphate solubilising bacteria isolated from different rhizospheric soils, only eleven isolates could produce halo zones on skim milk agar that showed protease activity (Chaiharn et al., 2008). Therefore, the above results showed that proteolytic activities varied among the test organisms, type of culture and cropped rhizosphere.

$\mathrm{HCN}$ inhibits the electron transport and thereby the energy supply to the cell is disrupted leading to the death of the organism. It inhibits proper functioning of enzymes and natural receptors by reversible mechanism of inhibition (Corbett, 1974). $\mathrm{HCN}$ is produced by many rhizobacteria and is postulated to play a role in biological control of pathogens (Defago et al., 1990). $\mathrm{HCN}$ is a volatile, secondary metabolite that 
suppresses the development of microorganisms and that also affects negatively the growth and development of plants (Siddiqui et al., 2006).

Siderophore are low molecular weight, high affinity $\left(\mathrm{Fe}^{+++}\right)$chelaters that transport iron into the bacterial cell (Leong, 1986). Buyer and Leong (1986) found that the fluorescent pseudomonads produced yellow green fluorescent siderophores (Pyoverdine type) under low iron condition membrane receptor proteins that recognize and take up Ferric pseudobactin complex. Siderophore sequester the trace amount of iron $\left(\mathrm{Fe}^{+++}\right)$from the rhizosphere and thereby limit the availability of $\mathrm{Fe}^{+++}$to the pathogen and ultimately suppress the pathogen growth (Scroth and Hancock, 1981). Siderophore production was postulated to be an important mechanism for the biocontrol activity of PGPR (Loper and Buyer, 1991and Bakker et al., 1993).

Kloepper et al., (1980) first demonstrated the importance of siderophore such as pseudobactin-10 in suppression of flax wilt caused by $F$. oxysporum. It has been reported that pyroverdine and pseudobactin siderophore produced by $P$. fluorescens and $P$. putida strain B10 were involved in the mechanism of PGP of potato (Kloepper et al., 1993).

Manivannan et al., (2012) assayed the in vitro screening of siderophore production by using Chrome Azurol S medium (CAS-medium). The culture of 10 isolates was streaked on the surface of CAS agar medium. Out of 10 PGPR, 5 isolates were able to produce siderophore and it was confirmed by the development of orange halos surrounding those colonies.

Extensive screening for the siderophore producing bacteria from the sugarcane rhizosphere was carried out by using the
Chrome Azurol S assay. Seven isolates were found to produce more than 85 per cent siderophore units (Tailor and Joshi, 2012). Among them, S-11 was found most efficient siderophore producer. S-11 was further characterized and identified as $P$. fluorescens.

Molecular characterization of $P$. fluorescens

16S Ribosomal RNA (16S rRNA) sequencing is widely and most popularly used in microbiological studies to identify the diversities in prokaryotic organisms as well as other. The advantages of using ribosomal RNA in molecular techniques are as ribosomes and ribosomal RNA are present in all cells and RNA genes are highly conserved in nature. So, $16 \mathrm{~S}$ rRNA gene sequencing has been established as the "gold standard" for identification and taxonomic classification of bacterial species. Woese and Fox, proposed the use of ribosomal RNA genes for molecular taxonomic research (Pace, 1997; Woese and Fox, 1977). Molecular characterization using 16S rRNA have been shown to be reliable and effective (Woese et al., 1984 and Woese, 1987).

$16 \mathrm{~S}$ rRNA is a type of RNA that plays a major role in synthesis of protein (Jayaram et al., 1991). As the mechanism of protein synthesis doesn't vary much from one organism to another, the RNA that assists the protein production also doesn't very much in evolution. The variations that occur are in predictable locations. It is observed that the nucleotide sequences of some portions of the $16 \mathrm{~S}$ ribosomal deoxyribonucleic acid (rDNA) are highly sealed. $16 \mathrm{~S}$ rRNA identifies organisms by comparing certain locations on a 16S rRNA molecule with a database of previously identified organisms whose $16 \mathrm{~S}$ rRNA mark is known. 16S rRNA is located in the major rRNA contains very well-conserved regions among biological species, which 
makes the comparison of $16 \mathrm{~S}$ rRNA sequences possible in studies of molecular evolution. 16S rRNA sequences also enable the identification of microorganisms because the 16S rRNA contains variable sequences that change according to different species. More than one 16S rRNA sequences may exist in a single bacterium. It is considered to be fast and better alternative to other methods of bacterial identification. Along with its use identifying the bacteria, $16 \mathrm{~S}$ sequencing can also be used to re-categorize the bacteria into new species (Kawanami et al., 1998).

Molecular biological methods using $16 \mathrm{~S}$ ribosomal ribonucleic acid (rRNA) gene sequences are commonly used for identifying and classifying bacteria. rRNA sequences are mainly used in ranking phylogenetic nomenclature including that of microorganisms (Hwang et al., 2011).

\section{P. fluorescens as plant growth promoter}

Fluorescent pseudomonads play very important role in enhancing and make availability of different nutrients including $\mathrm{P}$, $\mathrm{K}$ and micronutrients for plant and soil health enhancement. $P$. fluorescence and $P$. putida and other Pseudomonas sp. could enhance P and $\mathrm{K}$ availability, by production of organic acids and phosphatase enzymes. Siderophore producing Pseudomonas can also increase Fe solubility and uptake by plant. Predominant acid produced by various Pseudomonas sp. are Lactic acid, Malic acid, Oxalic acid (Taha et al., 1969), Tartaric acid, Citric acid (Krishnamurthy, 1989), Acetate, Citrate, Oxalate (Bader et al., 2006).

\section{ISR and SAR by $P$. fluorescens}

Murray and Walters (1992) studied the induction of systemic resistance to rust in Vicia faba by phosphate and EDTA. Generally, rhizobacteria mediated ISR signalling pathway does not involve SA or PR proteins (Kloepper et al., 1992). $P$. fluorescens had been shown to induce various defense genes in plants (Jakobek and Lindgren, 1993). But Maurhofer et al., (1994) showed that ISR induced by $P$. fluorescens strain $\mathrm{CHAO}$ in tobacco was associated with PR protein accumulation, suggesting that nonpathogen induced ISR and pathogen induced SAR share similar mechanisms. Rajappan et al., (1995) also reported the increased peroxidase activity in nickel nitrate treated and $X$. oryzae inoculated suspension cultured rice cells. Solorzano et al., (1996) observed the increase of PPO activity in tomato leaves treated with $\mathrm{NaH}_{2} \mathrm{PO}$. The pronounced increase was observed on PAL activity that was 2-3 times higher than the control. Reuveni et al., (1996) reported that the foliar sprays of NPK induced systemic protection against major pathogens of maize.

In arabidopsis, ISR triggered by $P$. fluorescens WCS417r was shown to be effective against the fungal root pathogen $F$. oxysporum fsp. raphani as well as the bacterial leaf pathogen $P$. syringae pv. tomato DC3000 (Pieterse et al., 1996). Treatment of rice seeds with $P$. fluorescens resulted in the significant reduction in BLB (Nayar, 1996). Chen et al., (2000) reported the systemic induction of defense enzymes in cucumber roots by treatment with $P$. fluorescens 63-44 and $P$. aureofaciens 63-28. Van Wees et al., (2000) demonstrated the compatibility and additivity of defense response activity by $P$. fluorescens WCS417r strain, because the strain induced the simultaneous activation of both ISR and SA dependent SAR pathway and resulted in an enhanced level of protection against $P$. syringae pv. tomato DC 3000. Thus rhizobacteria could suppress the disease caused by foliar pathogens by triggering the plant mediated resistance mechanism (Dube, 2001). Abbasi et al., (2002a) investigated the systemic resistance 
activity of potassium phosphate and ammonium lignosulphonate in tomato plants against the infection of Xav. Ton et al., (2002) analyzed the effectiveness of ISR and SAR by $P$. fluorescens WCS417r against the bacterial leaf pathogen $X$. campestris pv. armoraciae in arabidopsis. Graham et al., (2004) evaluated ISR compounds like harpins and actigard with and without copper hydroxide $(\mathrm{CuOH})$ and copper oxychloride $(\mathrm{CuOCI})$ in acid lime plants against $\mathrm{Xac}$ infection.

Abbasi et al., (2002b) reported that foliar application of potassium phosphate was effective in reducing the $X$. axonopodis $\mathrm{pv}$. vesicatoria infection in tomato and pepper plants by inducing the defense mechanism of the hosts.

Thangavelu et al., (2001) explained the ISR activity in banana plants treated with $P$. fluorescens accompanied by a significant increase in PAL, chitinase, $\beta$-1, 3-glucanase and phenolic contents.

Agostini et al., (2003) evaluated the resistance induction in different citrus cultivars against citrus scab, Alternaria brown spot and citrus melanose diseases by abiotic elicitors like Oxycom (HP2)' NutriPhite P+K (0-28-26), NutriPhite P, KeyPlex 350DP.

\section{Effect of micronutrient on aggressiveness of Pseudomonas fluorescens as biocontrol agents}

Kaur et al., (1979) found a reduction in brown spot disease of rice in both susceptible (Benibhog) and resistant (CH13) variety due to the application of iron @ 2.5 ppm. Kaur et al., (1979) concluded that the incidence of brown spot disease of rice could be brought down to a lower order of magnitude in the susceptible variety with proper manipulation of manganese.
Copper and iron, along with other transition metals, have incompletely filled d-orbitals, conferring strong redox activity; in aqueous solution, their ions may also participate in reactions as Lewis acids. These properties make these metals able to catalyse biochemical reactions, giving them an essential role in metabolism (Nies and Brown, 1998).

Results of Yang et al., (2004) suggested that zur gene is a functional member of the zinc uptake regulator (Zur) family that controls zinc and iron homeostasis, oxidative stress, and EPS production, which is necessary for virulence in $X$. oryzae pv. oryzae. To understand the gene of zinc uptake regulator (Zur) involved in virulence of the pathogen in rice, they generated a mutant OSZRM by homologous suicide plasmid integration. The mutant failed to grow in NYGB medium supplemented with $\mathrm{Zn}^{2+}$ or $\mathrm{Fe}^{3+}$ at a concentration of $5001 \mathrm{M}$ or $6 \mathrm{mM}$, whereas the wild-type strain grew well at the same conditions. The zur mutant was hypersensitive to hydrogen peroxide and exhibited reduction catalase activity and the production of extracellular polysaccharide (EPS). Interestingly, the mutant showed a reduction in virulence on rice but still kept triggering hypersensitive response (HR) in tobacco. When the mutant was complemented with the zur gene, the response was recovered to wild-type.

Khalil and Olsson (2013) studied the effects of micronutrients and its interaction with the commercial biocontrol product Binab $\mathrm{T}$ against the root pathogen Pythium ultimum in order to identify supporting factors to increase the efficiency of biocontrol agents in closed cultivation systems.

Zinc is often included in discussions of transition metals, but it does not have an incomplete d-orbital, and it does not 
participate in redox reactions. Instead, its stability makes it an ideal cofactor for enzymatic reactions that require a stable metal ion to act as a Lewis acid during catalysis. Estimates suggest that as high a fraction as one third of all proteins require some metal cofactor (Waldron and Robinson, 2009). In illustration of the importance of these metals to all life forms, consider that iron has essential roles in oxygen metabolism, electron transport, lipid metabolism and the tricarboxylic acid (TCA) cycle; in fact, there are known to be over 100 metabolic enzymes with iron-based cofactors (Masse and Arguin, 2005; Miethke and Marahiel, 2007). So fundamental are some of its uses that bacteria have been found to have controls both at the gene expression and post-transcriptional level to ensure that iron is directed to the most essential proteins when it is in limited supply (Masse and Gottesman, 2002; Masse and Arguin, 2005; Zaini et al., 2008). Zinc is necessary for the functioning of DNA/RNA polymerase enzymes and of ribosomes and in superoxide dismutase (SOD) (Zelko et al., 2002). Zinc also has particular importance for plants, being found in carbonic anhydrase and in stromal processing peptide, and thus contributing to photosynthesis. Additionally, zinc is important for protein structure, with 4 per cent of Arabidopsis proteins, for example, containing zinc finger domains (Hansch and Mendel, 2009). Copper is needed in cytochrome oxidases (Waldron and Robinson, 2009), ascorbate oxidase (Santagostini et al., 2004), SOD (Zelko et al., 2002), polyphenol oxidase (Marusek et al., 2006) and, in plants, in the receptor for the hormone ethylene, an important signal in plant development and disease resistance (Rodriguez et al., 1999). These essential roles are by no means an exhaustive list of the functions of these metals in vivo.

Given the essential role of metals in living organisms, it is clear that either a lack, or an excess of essential metals may have a profound effect on a wide range of organisms, and by extension, their interactions. Add to this the fact that availability varies widely in natural situations-zinc, for example, is present at varying concentrations in different soil types (Reeves and Baker, 2000; Hotz and Brown, 2004), including growth limiting concentrations in many agricultural soils and it becomes clear that the impact of these metals on plant-pathogen interactions must be taken into consideration in economically important agricultural settings. To gain more insight into the impact of varying metal availability on plant disease it will be necessary to consider in what ways these metals are available to both partners in this interaction.

Certain bacteria, including the opportunistic pathogen Burkholderia cenocepacia, can obtain iron directly from host iron-chelating proteins such as ferritin (Whitby et al., 2006). These abilities, however, are known to have become the subject of an evolutionary arms race between bacterium and host in vertebrate pathosystems (Skaar, 2010), an outcome which also seems likely in phytopathology. This makes the indirect pathway of siderophore production more stable, although there are also clear advantages for a bacterium in being able to assimilate siderophores produced by other organisms, including the host (Miethke and Marahiel, 2007). Interestingly, however, it has recently begun to emerge that some so-called secondary siderophores, which have much lower affinities for iron than other siderophores produced by the same organism, may be important for the acquisition of other metals, including zinc (Leach et al., 2007). Redox active metals are not simply required for life. A delicate balance must be maintained, because these metals have the potential to become toxic at excess concentrations. Copper, for example, is able to displace other 
metals from complexes and to generate reactive oxygen species (ROS). Similarly, iron is a potent generator of ROS (Miethke and Marahiel, 2007), which is the necessary corollary of the redox activity that makes it so fundamentally useful. ROS may cause oxidative stress and damage to cells (Fones and Preston, 2012). The observation that the toxic metal, cadmium, kills cells by creating waves of $\mathrm{H}_{2} \mathrm{O}_{2}$ and superoxide illustrates the damaging potential of ROS (Garnier et al., 2006). Additionally, excess metals may compete with required cofactors for binding sites in transport proteins and enzymes (Stohs and Bagchi, 1995; Hanikenne, 2003). This results in a need for stringently controlled metal ion homoeostasis, and mechanisms for tolerating elevated metal concentrations. From the perspective of plant pathogenesis it is interesting to note that the regulation or expression of a number of metal tolerance systems alters during host-bacteria interactions. For instance, the cueA gene is upregulated in the plant growth promoting rhizobacterium $P$. fluorescens SBW25 when growing on the surface of sugar beets (Zhang and Rainey, 2008) and it has been found that this gene is important for colonisation of plant hosts (Zhang and Rainey, 2007). The copRSCD genes present in a strain of $P$. fluorescens isolated from a diseased fish have been implicated in spread and survival in host tissues, as well as copper resistance (Hu et al., 2009). In plants as well, metal resistance systems appear to play a role during interactions with pathogens. For instance, metallothioneins are known to be upregulated in Arabidopsis, tobacco and velvetleaf during infection (Dauch and Jabaji-Hare, 2006), while phytochelatin synthesis has been linked to basal defence responses (Clemens and Persoh, 2009). There are a number of ways in which metals can influence the ability of a micro-organism to be pathogenic on a plant host. Their most obvious impact is in terms of metal availability to support bacterial growth in plant tissues. However, metals can also be involved in the regulation of pathogenesis and virulence genes, both directly and indirectly. Fur controls the expression of iron uptake and iron storage systems in an iron dependent manner (McHugh et al., 2003 and Butcher et al., 2011). The mode of action of the Fur protein has been well studied in E. coli, where it is known to form a complex with $\mathrm{Fe}^{2+}$, which binds to a 'fur box' sequence in the promoter of various genes. In the absence of iron, Fur cannot bind and repression of transcription of these genes is released (Bagg and Neilands, 1987). As well as this negative regulation, Fur can activate genes by repressing the transcription of the small RNA, RyhB, which, when expressed, causes degradation of mRNAs encoding iron utilising enzymes (Masse and Gottesman, 2002). However, the role of Fur is not restricted to effects upon iron metabolism. Instead, Fur behaves as a global regulator of gene expression, with involvement in acid tolerance, oxidative stress tolerance, toxin production and the expression of virulence factors (Kitphati et al., 2007), making iron and fur critical for pathogenesis (Ratledge and Dover, 2000). In some bacteria, including the plant symbionts Rhizobium leguminosarum and Sinorhizobium meliloti, fur has been found to regulate manganese uptake, while losing its role in iron homoeostasis (Johnston et al., 2007). This is also the case in the tumour-inducing pathogen Agrobacterium tumefaciens, where the gene is renamed mur. Despite regulating a different metal, mur remains essential for full virulence (Kitphati et al., 2007). A zur knock-out mutant in the related bacterium $X$. campestris shows reduced zinc tolerance and reduced virulence (Tang et al., 2005). It is possible, however, that the virulence effect in this instance may be attributable to the fact that the mutant produces lower quantities of extracellular polysaccharides (EPS), which are important for virulence ( $\mathrm{Yu}$ et al., 1999; Fones and 
Preston, 2012). Additionally, fur is known to regulate the expression of T3SS genes in animal pathogens such as Salmonella enteric (Ellermeier and Slauch, 2008) suggesting that this link between metal regulation and the expression of the hrp cluster is unlikely to be confined to Xanthomonas. Indeed, it is known that iron nutrition can affect hrp gene expression in $P$. syringae (Bronstein et al., 2008 and Kim et al., 2009, 2010). Other plant colonisation and virulence factors shown to be regulated by iron include type IV pili in $X$. fastidiosa (Zaini et al., 2008) and exoenzyme production in soft rot pathogens such as Dickeya dadantii (Franza et al., 2002).

Evidence of a role for siderophore synthesis and iron uptake in the pathogenesis of $P$. syringae was suggested in work by Bronstein et al., (2005) showed that mutants of $P$. syringae pv. tomato DC3000 lacking the twin-arginine translocation (tat) system had reduced siderophore synthesis, reduced iron uptake and decreased virulence. More direct evidence was provided by a study showing that siderophore-deficient mutants of $P$. syringae pv. tabaci were impaired in their ability to infect tobacco (Taguchi et al., 2010). Pseudomonas syringae pv. tomato produces two siderophores, yersiniabactin and pyoverdine, and is also able to use citrate as an iron chelator (Buell et al., 2003; Jones et al., 2007; Jones and Wildermuth, 2011). However, siderophore-deficient mutants of $P$. syringae pv. tomato, although impaired in iron uptake in vitro, remained fully pathogenic in tomato. Similarly, siderophore mutants of the bean pathogen $P$. syringae pv. phaseolicola 1448A and the sweet cherry pathogen $P$. syringae pv. syringae B301D were shown to retain virulence when inoculated into bean pods and cherry fruit, respectively (Cody and Gross, 1987; Owen and Ackerley, 2011). Studies of a number of other plant pathogenic bacteria, including the rice pathogen $X$. oryzae pv. oryzae, the gram- positive plant pathogen Streptomyces scabies, the wilt pathogen Ralstonia solanacearum and $A$. tumefaciens have also failed to demonstrate a role for siderophore synthesis in plant pathogenesis (McQueen and Schottel, 1987; Bhatt and Denny, 2004; Rondon et al., 2004; Pandey and Sonti, 2010; Seipke et al., 2011). Several explanations have been put forward to explain why siderophore-deficient mutants of some plant pathogenic bacteria remain fully virulent in plant hosts. It has been suggested that pathogens are able to acquire iron from plant iron compounds such as heme/hemin or ironnicotiamine, or that iron levels in plant tissues are sufficient to support pathogen growth in the absence of siderophore synthesis (Bhatt and Denny, 2004; Jones and Wildermuth, 2011). Iron complexes with phytic acid (myo-inositol hexakisphosphate, InsP6) and other myoinositol trisphosphate and tetrakisphosphate regio-isomers have also been suggested to be a source of iron for plant pathogenic bacteria (Smith et al., 1994 and Hirst et al., 1999).

Genome sequence analyses have revealed a greater degree of functional diversity and functional redundancy in many plant pathogens than previously anticipated, with pathogens such as $P$. syringae pv. actinidiae containing genes for the production of multiple siderophores, including pyoverdine, enterobactin and yersinabactin (Scortichini et $a l .$, 2012). Finally, it has been suggested that some of these bacteria have novel iron chelation systems that act as alternative mechanisms for iron uptake in the absence of siderophore synthesis. For example, Grinter et al., (2012) have recently shown that two ferredoxin containing bacteriocins produced by the soft rot pathogen $P$. carotovorum can enhance bacterial growth in the presence of spinach ferredoxin under iron-limiting conditions, suggesting that plant ferredoxins can be used as an additional source of iron. 
The activity of iron chelation systems may be enhanced by the activity of compounds such as phenazine-1-carboxylic acid, produced by the opportunistic pathogen $P$. aeruginosa, which can act to reduce $\mathrm{Fe}^{3+}$ to $\mathrm{Fe}^{2+}$ increasing iron availability in host tissues (Wang et al., 2011). Despite the lack of evidence for a role for siderophore synthesis in the growth of many plant pathogenic bacteria inside plant tissues, siderophores have been shown to have an important role in the earliest stages of the $P$. syringae infection cycle. Pseudomonas syringae pv. syringae $\mathrm{B} 728 \mathrm{a}$ and $P$. syringae pv. phaseolicola 1448A produce two siderophores, pyoverdine, in common in with $P$. syringae pv. tomato and other pseudomonads, and achromobactin, in common with D. dadantii (Berti and Thomas, 2009; Owen and Ackerley, 2011). Mutants of the epiphytic strain $P$. syringae pv. syringae $22 \mathrm{~d} / 93$ deficient in either pyoverdine or achromobactin synthesis showed reduced epiphytic growth on soybean leaves when spray inoculated onto the leaf surface, with a double mutant lacking both siderophores showing an even greater reduction in growth (Wensing et al., 2010). This reduction was not evident when bacteria were wound inoculated into leaves, indicating that wound sites leaked sufficient iron to support bacterial growth. It is interesting to note that for opportunistic pathogens such as $P$. aeruginosa and $B$. cenocepacia the requirement for siderophore synthesis differs between plant and animal hosts, with siderophores playing a more central role in animal models of infection. For example, pyoverdine and ornibactin-deficient mutants of B. cenocepacia showed only a slight reduction in the ability to infect alfalfa, but were strongly attenuated in their ability to infect Galleria mellonella and Caenorhabditis elegans (Uehlinger et al., 2009). It has been shown that some plant pathogenic bacteria, including $P$. syringae, Pantoea stewartii and D. dadantii can be disseminated by insect vectors such as aphids (Grenier et al., 2006; Stavrinides et al., 2009, 2010), and it is possible that siderophore-mediated iron uptake plays an important role in these interactions.

Finally, it is also important to note that there may be counter-selection against the use of certain siderophores during plant colonisation, as the pseudomonad siderophore pyoverdine can be recognised and assimilated by Arabidopsis, thus both alerting the plant to the presence of the invader and providing it with an iron source (Vansuyt et al., 2007). Indeed, the enterobactin genes of closely related $P$. carotovorum strains have been shown to be highly polymorphic (Bull et al., 1994), suggesting selection for diversity among these enzymes and their products, which may be driven by plants or other microorganisms.

Beyond their role in iron acquisition, siderophores are implicated in the regulation of many essential virulence functions; for example, pyoverdine can, via the TonB dependent siderophore receptor, induce both itself and the important virulence factors exotoxin A and endoprotease in $P$. aeruginosa (Vasil, 2007). Pseudomonas syringae pv. tabaci mutants deficient in pyoverdine synthesis were found to be deficient in production of tabtoxin and EPS, and to show severely reduced virulence following both infiltration and spray inoculation (Taguchi et al., 2010). Greenwald et al., (2012) used RNAseq analysis to show that the extracytoplasmic sigma factor AcsS regulates achromobactin synthesis in $P$. syringae $\mathrm{pv}$. syringae $\mathrm{B} 728 \mathrm{a}$ and found that AcsS-deficient mutants showed altered expression of 287 genes, including genes associated with motility, toxin synthesis and EPS synthesis. Zinc is also used as an antimicrobial which can be applied to crops; for example, zinc has been shown to prevent fungal spore germination via the production of toxic levels 
of ROS (Montag et al., 2006), while zinc sulphate and zineb (zinc ethylene bisdithiocarbamate) were found to inhibit growth of the bacterial pathogen $X$. campestris pv. vesicatoria (Adaskaveg and Hine, 1985). However, again there is evidence that strains can rapidly become resistant to zinc compounds (Adaskaveg and Hine, 1985; Fones et al., 2010). Copper, streptomycin and zinc compounds have been used in combination to control bacterial plant disease, and there is evidence that bacteria can acquire resistance to all three compounds (Ward and O'Garro, 1992). There are a number of metalloenzymes that are important for plant defence (Wu et al., 2011), meaning that the availability of these metals to the plant can be an important factor in the outcome of the plant-pathogen interaction. Metal-induced ROS have a number of important roles both in defensive signalling and as antimicrobials (Wojtaszek, 1997). Finally, metal stress, either as deficiency or excess, can act as a 'priming' stimulus for plant defence, via the overlapping pathways by which plants signal biotic and abiotic stress (Mithofer et al., 2004).

Graham (1983) states that the balance of an interaction between plant and pathogen can be tipped by changes in micro nutrition, especially when the plant is deficient in, or has access to excess levels of, a trace element. This may be most important in cases where the pathogen has not had the opportunity to co-evolve with the plant; for example when it has newly arrived in the plant's environment. Such a pathogen would, of course, be likely to lack tolerance mechanisms for the lack or excess of an element, allowing the plant to turn this contingency to its advantage. The disruption of the pathogen's supply of metal is an obvious strategy for disease resistance, considering that microorganisms and host organisms are in competition for metal ions (Bullen, 1981; Hammer and Skaar, 2012).
Thus, it is to the plant's advantage to ensure that metals are diverted from the pathogen to plant cells. In this context, the most relevant metal to consider is iron. Iron is one of the most abundant elements in the world (Expert et al., 1994), but in aerobic environments it mostly exists as the insoluble $\mathrm{Fe}^{3+}$ ion, so that its bioavailability is comparatively low (Touati, 2000). This makes iron one of the most intensely competed ions during hostpathogen interactions (Payne, 1993; Weinberg, 1993; Johnson, 2008; Nairz et al., 2010). The host strategy of withholding iron to limit pathogen growth has been particularly well documented in mammalian systems (Bezkorovainy, 1981; Ward and Connelly, 2004 and Nairz et al., 2010). Iron withholding via sequestration by storage proteins such as transferrin and lactoferrin is common in vertebrates and invertebrates, and can be effective, as iron is needed for bacterial growth, pathogenicity and biofilm formation (Ong et al., 2006). The last of these is of great importance clinically, as the restriction of pathogen iron supply by lactoferrin can prevent necessary signalling for the development of drug-resistant biofilms (Singh et al., 2002 and Banin et al., 2005).

More evidence for the importance of iron withholding in plant-pathogen interactions comes from investigations into the role of NRAMP metal transporting proteins in Arabidopsis. These proteins are, again, known from mammalian systems where they appear to have a role in regulating the concentrations of iron, zinc and manganese to which pathogens are exposed within macrophages (Gunshin et al., 1997; Forbes and Gros, 2001; Goswami et al., 2001). NRAMPs occur throughout the diversity of life and have recently been characterised in plants, including Arabidopsis, where they have been shown to function as uptake pumps for iron and manganese (Curie et al., 2000). Certain of these NRAMPs are upregulated under biotic 
stress and iron starvation, and NRAMP3 and 4 have been found to be involved in basal resistance to $D$. dadantii in a manner independent of other defence associated signals such as salicylic acid and jasmonate (Segond et al., 2009). As noted previously, there is evidence that in some interactions pathogen invasion causes iron starvation, and the presence of bacterial siderophores can induce the iron storage protein FER1 (Dellagi et al., 2005 and Boughammoura et al., 2007). Thus, bacteria induced iron deficiency may provide the link between NRAMP proteins and defence. Additionally, it was found that a double knockout mutant, nramp3nramp4, has an attenuated oxidative burst, providing the suggestion that these transporters might be involved in providing $\mathrm{Fe}^{3+}$ for Fenton reactions for the generation of ROS (Segond et al., 2009).

Iron is not the only metal which may be withheld as a form of defence. In mammalian systems, the protein calprotectin is used by neutrophil cells to prevent bacterial growth by preventing pathogens from acquiring zinc (Clohessy and Golden, 1995). Not only can this prevent the growth of bacteria, but it can also disable zinc-dependent SOD, rendering the bacteria more susceptible to bactericidal ROS production by neutrophils (Kehl-Fie et al., 2011). As yet, there is limited evidence for zinc-withholding as a means of pathogen defence in plants, although it is thought that metal-chelating chemicals such as polyphenols may restrict the availability of multiple metal ions, including zinc and copper (McDonald et al., 1996 and Mila et al., 1998). The bacterium $X$. oryzae pv. oryzae, which, when growing in the xylem of rice, can be limited by high concentrations of copper (Yuan et al., 2010). The importance of this for the outcome of this plant pathogen interaction is illustrated by the evolution of a bacterial TAL effector protein that initiates transcription of $\mathrm{Xa13}$, a rice gene encoding a transmembrane transporter that works in concert with two additional rice proteins to remove copper from the xylem (Yuan et al., 2011).

It has been suggested that a novel Arabidopsis MFS-family zinc transporter, an orthologue of which is induced by pathogen infection in maize (Simmons et al., 2003), release zinc from the vacuole in infected tissues and play a role in defence (Haydon and Cobbett, 2007). Moreover, zinc acts to limit bacterial growth by competing for manganese transporters (McDevitt et al., 2011). The NRAMP proteins may also function to transport manganese (Segond et al., 2009). As well as affecting pathogens directly through direct deficiency or toxicity, metals can affect plant pathogen interactions indirectly via their inclusion in metalloenzymes. Two metalloenzymes of particular importance in plant pathogen interactions are SOD, which exists as three isoforms that can be separated according to their metallic cofactors of $\mathrm{Fe}, \mathrm{Mn}$ and $\mathrm{Cu} / \mathrm{Zn}$ (Kliebenstein et al., 1998 and Wu et al., 2011) and catalase, which relies for its activity on four heme groups (Reid et al., 1981 and Willekens et al., 1995). During the oxidative burst, plants produce such high concentrations of ROS that their own antioxidant defences are temporarily overwhelmed (Vanacker et al., 1998).

To prevent escalating damage to plant cells, it is essential that the plant possesses functional antioxidant enzymes to regain control of ROS levels at the appropriate time. Indeed, it is known that control of ROS levels is important in the plant's response to both biotic and abiotic stresses (Mittler, 2002; Prashanth et al., 2008). Some plant pathogens attempt to manipulate ROS production by the host as part of their pathogenicity (Fones and Preston, 2012). For example, the phytotoxin coronatine, employed by many strains of $P$. syringae and by the soft rot pathogen 
Pectobacterium atrosepticum, causes lightdependent upregulation of ROS production and a concomitant suppression of SOD activity, and is essential for full virulence of these pathogens (Bender et al., 1987; Ishiga et al., 2008, 2009; Uppalapati et al., 2008). Similarly, $P$. aeruginosa produces a redox active phenazine toxin called pyocyanin, which induces ROS production and systemic resistance in plants and animals, but enhances susceptibility to the fungal pathogen Rhizoctonia solani in rice (Mahajan-Miklos et al., 1999; O'Malley et al., 2003; De Vleesschauwer et al., 2006). Another enzyme which is important in plant defence is the pathogen-related protein, PR-10, of Theobroma cacoa. This protein is a ribonuclease, which, when released during pathogen-induced programmed cell death, is internalised by fungal cells and can act as a fungicidal toxin against Moniliophthora perniciosa, the causal agent of witches' broom disease (Pungartnik et al., 2009). Although the exact mechanism of toxicity is unclear, it has been demonstrated that toxicity is reduced if a fungal high-affinity copper transporter is not expressed, suggesting that either copper is needed for PR-10 enzyme activity, or that the toxin works by disrupting copper homoeostasis in the pathogen (Pungartnik et al., 2009). In a separate study, over-expression of maize ZmPR10.1 in $A$. thaliana was found to cause increased susceptibility to $P$. syringae pv. tomato and $\mathrm{Cu}^{2+}$ was identified as an inhibitor of ZmPR10 and ZmPR10.1 RNase activity (Xie et al., 2010). The final two aspects of the involvement of metals in plant defence we will cover in this section concern their role in the generation of ROS. ROS are understood to have a number of pivotal roles in plant defence, both as antimicrobials produced at the site of infection (Peng and Kuc, 1992; Lamb and Dixon, 1997; Wojtaszek, 1997) and as signals for further defence responses (Alvarez et al., 1998; Love et al., 2005;
Torres et al., 2006; Choi et al., 2007; Van Breussegem et al., 2008). Redox active metals, particularly iron, can participate in Fenton reactions by which hydroxide radicals may be generated from $\mathrm{H}_{2} \mathrm{O}_{2}$ (Pierre and Fontecave, 1999).

Cereal crops traffic large vesicles containing $\mathrm{H}_{2} \mathrm{O}_{2}$ and $\mathrm{Fe}^{3+}$ to the site of Blumeria graminis infection, where they appear to participate in the oxidative burst; similarly, the ABC transporter ATPEN3, which is involved in the translocation of the redox active metal, cadmium, has been found to be involved in resistance to $P$. syringae and Phytophthora infestans (Huckelhoven, 2007). Iron appears to be involved in a feed-forward mechanism controlling ROS generation, for as well as participating in the generation of ROS, its efflux can also be signalled by $\mathrm{H}_{2} \mathrm{O}_{2}$ (Lui et al., 2007).

In addition to this direct role in the defensive production of antimicrobial ROS, metals can induce ROS in plants by acting as stressors (Boominathan and Doran, 2003; Garnier et al., 2006). Since ROS are important signals in the plant response to pathogen invasion, it is perhaps unsurprising that there is evidence of cross-talk between metal stress and pathogen resistance (Mithofer et al., 2004). ROS, whether generated by biotic or abiotic stress, can induce the production of oxylipins, which also have signalling roles in plant defence (Blee, 2002 and Mithofer et al., 2004). Although, the mechanism has not been fully elucidated, low-intensity spraying of crops with nickel can induce phytoalexin production and protect against fungal infection (Wood and Reilly, 2007). It is logical to speculate that this effect may also be due to common signalling pathways between nickel and pathogen stress. There is, however, also evidence of a synergistic effect of metal and pathogen stress, in which each may increase the susceptibility of the plant to the other 
(Stroniski and Floriszak, 1990; Miteva et al., 2001).

\section{Analysis of available micronutrients in soil}

Kumar and Babel (2011) found that the availability of micronutrients increased significantly with increase in finer fractions (silt and clay) because these fractions are helpful to improve soil structure and aeration which are favourable conditions for increasing its availability. The available micronutrients were found to increase with increase in CEC of soils due to more availability of exchange sites on soil colloids. Similarly, the availability of micronutrients enhanced significantly with increase in organic matter because: (i) organic matter is helpful in improving soil structure and aeration, (ii) organic matter protects the oxidation and precipitation of micronutrients into unavailable forms and (iii) supply soluble chelating agents which increase the solubility of micronutrient contents. On the other hand, its availability was found to be reduced with increase in $\mathrm{pH}$ and $\mathrm{CaCO}_{3}$ content of soils and high $\mathrm{pH}$ is responsible for its oxidation. Thus, most readily available form of micronutrients converts into less soluble form after oxidation. Hence, the availability of micronutrients is reduced at higher $\mathrm{pH}$ level. Besides, at high $\mathrm{pH}$ micronutrients are also precipitated as insoluble form which reduces its availability.

The similar findings reported by Sharma et al., (2003) indicated that the available $\mathrm{Zn}, \mathrm{Cu}$, $\mathrm{Fe}, \mathrm{Mn}$ and $\mathrm{B}$ contents in soils of Nagaur district of Rajasthan ranged from 0.1 to 1.7 , 0.5 to $3.9,1.0$ to $6.6,2.7$ to 7.2 and 0.2 to 2.0 $\mathrm{mg} \mathrm{kg}{ }^{-1}$ with the mean values of $0.73,2.11$, 4.32, 5.15 and $0.68 \mathrm{mg} \mathrm{kg}^{-1}$, respectively and then found available $\mathrm{Zn}, \mathrm{Fe}$ and $\mathrm{B}$ were deficient in 46, 51.5 and 26.5 per cent soil samples, respectively, while $\mathrm{Cu}$ and $\mathrm{Mn}$ were adequate in all the soil samples. Choudhary and Shukla (2004) reported that the available boron content varied from 0.25 to $7.10 \mathrm{mg} \mathrm{kg}$ ${ }^{1}$ and 0.22 to $1.15 \mathrm{mg} \mathrm{kg}^{-1}$ with mean values of 1.51 and $0.51 \mathrm{mg} \mathrm{kg}^{-1}$ in irrigated and rainfed soils of western Rajasthan, respectively. High content of boron in irrigated soils was due to high boron content in irrigation water. The 48.1 per cent of Indian soils were deficient in DTPAextractable $\mathrm{Zn}, 11.2$ per cent in Fe, 7 per cent in $\mathrm{Cu}$ and 5.1 per cent in Mn (Gupta, 2005). Murthy (2006) also observed that boron deficiency is a global phenomenon, at present, nearly 33 per cent of Indian soils were found deficient in available boron.

Singh (2008) also reported that the analyzed of soil and plant samples had indicated that 49 per cent of soils in India are potentially deficient in Zn, 12 per cent in Fe, 5 per cent in $\mathrm{Mn}, 3$ per cent in $\mathrm{Cu}, 33$ per cent in B. Later on, Sidhu and Sharma (2010) reported that the DTPA-extractable $\mathrm{Zn}$ in Trans-Gangetic Plains ranged from 0.11 to $5.08, \mathrm{Cu}$ ranged from 0.22 to 4.72, Mn ranged from 2.9 to 101.2 and $\mathrm{Fe}$ ranged from 1.05 to $97.9 \mathrm{mg} \mathrm{kg}$ ${ }^{1}$. In the Upper Gangetic Plains, the DTPAextractable $\mathrm{Zn}$ ranged from 0.04 to $2.53, \mathrm{Cu}$ ranged from 0.06 to 4.32 , $\mathrm{Mn}$ ranged from 11.1 to 421.0 and $\mathrm{Fe}$ ranged from 3.48 to 90.2 $\mathrm{mg} \mathrm{kg}^{-1}$. In the Middle Gangetic Plains, the DTPA-extractable $\mathrm{Zn}$ ranged from 0.17 to 8.60, $\mathrm{Cu}$ ranged from 0.09 to $7.80, \mathrm{Mn}$ ranged from 3.0 to 155.1 and $\mathrm{Fe}$ ranged from 9.22 to $256.7 \mathrm{mg} \mathrm{kg}^{-1}$. In the Lower Gangetic Plains, the DTPA-extractable $\mathrm{Zn}$ ranged from 0.04 to 3.46, Cu ranged from 0.21 to 4.38 , Mn ranged from 9.54 to 252.2, and $\mathrm{Fe}$ ranged from 3.60 to $182.5 \mathrm{mg} \mathrm{kg}^{-1}$. The $\mathrm{Zn}, \mathrm{Cu}, \mathrm{Fe}, \mathrm{Mn}$ and $\mathrm{B}$ showed positive correlations with silt plus clay and organic carbon, and negative correlations with $\mathrm{pH}$ and calcium carbonate content (Sharma et al., 2003).

Sharma et al., (2004) investigated that the total content of micronutrients $(\mathrm{Fe}, \mathrm{Cu}, \mathrm{Zn}$, 
Mn) increased with an increase in clay and silt and CEC, whereas DTPA-extractable micronutrient increased with an increase in organic carbon content and CEC and decreased with increasing $\mathrm{pH}$, sand and calcium carbonate content. Moafpouryan and Shukla (2004) observed that the water soluble, non-specifically adsorbed and specifically adsorbed boron were significantly and positively correlated with organic carbon, CEC and clay content. Mathur et al., (2006) reported that the DTPA-extractable zinc was significantly and negatively correlated with $\mathrm{pH}\left(\mathrm{r}=-0.383^{* *}\right), \mathrm{CaCO} 3\left(\mathrm{r}=-0.196^{*}\right)$, and sand $\left(\mathrm{r}=-0.395^{* *}\right)$ and positively correlated with organic carbon $(\mathrm{r}=+0.738 * *)$, CEC $(\mathrm{r}=$ $\left.+0.875^{* *}\right)$ and clay content $\left(\mathrm{r}=+0.385^{* *}\right)$.

Yadav (2008) find out that the available Fe, $\mathrm{Mn}, \mathrm{Cu}$ and $\mathrm{Zn}$ showed positive and significant correlation with organic carbon and also found negatively and significantly correlated with $\mathrm{pH}$ and calcium carbonate content of soils. Yadav and Meena (2009) reported that the availability of zinc increased significantly with increase in clay $(\mathrm{r}=$ $\left.+0.597^{* *}\right)$, organic carbon $\left(\mathrm{r}=+0.896^{* *}\right)$, EC $\left(\mathrm{r}=+0.305^{*}\right)$ and CEC $\left(\mathrm{r}=+0.527^{* *}\right)$. On the other hand, the availability of zinc was reduced significantly with an increase in $\mathrm{CaCO}_{3}(\mathrm{r}=-0.718 * *)$ and $\mathrm{pH}(\mathrm{r}=-0.618 * *)$ of soil. Sidhu and Sharma (2010) also reported that the available micronutrients $(\mathrm{Zn}$, $\mathrm{Cu}, \mathrm{Mn}$ and $\mathrm{Fe}$ ) increased with increase in organic carbon and decreased with increase in sand content, $\mathrm{pH}$ and calcium carbonate.

\section{Defense related gene expression}

In response to a pathogen, the host plant expresses various degrees of resistance which is usually classified into two categories namely qualitative resistance and quantitative resistance. Qualitative resistance is generally controlled by major genes while quantitative resistance is controlled by polygenic factors.
Till now, about twenty-one major BB resistance genes have been identified (Mew et al., 1992). More recently, a locus for resistance to $\mathrm{BB}$ was transferred from the wild species Oryza longistaminata to the cultivated rice line IR24 generating the introgression line IRBB21 (Khush et al., 1990). This locus, $X a 21$, was found to confer resistance to all known Xoo races in India and Philippines (Khush et al., 1990 and Ikeda et al., 1990). Recently, a gene at this locus has been cloned (Xa21) (Wang et al., 1996) which is the member of a small multigene family of kinases. Most of these family members are linked, suggesting that $\mathrm{Xa21}$ is part of a complex locus (Song et al., 1995). The structure of Xa21 represents a previously uncharacterized class of cloned resistance genes. The deduced amino acid sequence of Xa21 encodes a receptor kinase-like protein carrying leucine-rich repeats (LRR) in the putative extracellular domain, a single pass transmembrane domain, and a serine threonine kinase intracellular domain (Song et al., 1995).

Earlier studies have determined if the multiisolate resistance observed for line IRBB21 was due to a single gene or multiple genes at the Xa21 locus. For example, the locus may encode a single gene product $X a 21$, that specifies resistance to multiple pathogen isolates, or the locus may be composed of a cluster of tightly linked genes, each of which recognizes a unique isolate-specific determinant. Wang et al., (1996) reported that transgenic plants expressing the cloned $\mathrm{Xa21}$ gene conferred multi-isolate resistance to 29 diverse isolates from eight countries. However, recent studies have shown that Nepalese strains were virulent on $R$ gene $X a 21$ present in rice line IRBB21 (Adhikari et al., 1999). A sub-population of Xoo virulent to rice line IRBB21 from a pathogen population isolated from a BB epidemic that occurred in 1998 in Kerala (Brindha Priyadarisini and Gnanamanickam, 1999). 
Therefore, the usefulness of Xa21 to the Indian subcontinent and South Asia may be in doubt. While, the near isogenic line IRBB21 carrying $\mathrm{Xa21}$ was susceptible to this subpopulation, rice line NH56 carrying four $R$ genes $(X a 4+x a 5+x a 13+X a 21)$ was found to be resistant (Huang et al., 1997).

Quantitative resistance of rice varieties to $\mathrm{BB}$ is complicated for genetic analysis because of their continuous variation with no distinct classes in a segregating population. Washio et al., (1966) were the first to report the slow lesion-developing type of resistance (quantitative) in Japan which was controlled by polygenes. Many workers have also identified varieties showing polygenic resistance to BB (Wasano et al., 1979; Horino and Yamada, 1979; Wasano, 1982; Yamada, 1986). Inspite of the voluminous data available, more research is needed to understand the nature of quantitative resistance to $\mathrm{BB}$.

According to Wang et al., (2006), Xa21 is a receptor-like kinase protein in rice (Oryza sativa) that confers gene-for-gene resistance to specific races of the causal agent of bacterial blight disease, Xoo.

Ponciano et al., (2007) examined the relationship between Pathogenesis Related (PR) defense gene expression and Xa21mediated developmental disease resistance induced by Xoo. They found that the adult stage leaves are more competent to express OsPR1 genes.

In conclusion bacterial blight is an important constrain to rice production and application of bioagent formulations exhibited long lasting effect in reducing the disease compared to chemical control. Moreover, use of mixture of strains and enhancement of antibiotic biosynthesis are the main approaches that have been reported to improve the efficacy of
P. fluorescens and other biocontrol strains. It has been seen that zinc amendments improved the biocontrol activity of $P$. fluorescens and enhanced the efficacy in performance of $P$. fluorescens and induced host defense by induction of pathogenesis related $(P R)$ and $X a$ genes. However, studies regarding fundamental aspects of $P R$ s gene particularly the exact mechanisms of gene regulation remained little understood. Thus, the molecular targets involved in PRs induction are a challenge for both fundamental and applied studies.

\section{References}

Adhikari, T.B., Basnyat, R.C. and Mew, T.W. 1999. Virulence of Xanthomonas oryzae pv. oryzae on rice lines containing single resistance genes and gene combinations. Plant Dis., 83: 46-50.

Adhikari, T.B., Vera Cruz, C.M., Zhang, Q., Nelson, R.J., Skinner, D.Z., Mew, T.W. and Leach, J.E. 1995. Genetic diversity of Xanthomonas oryzae pv. oryzae in Asia. Appl. Environ. Microbiol., 61: 966-971.

Annonymous. 2004. International Rice Research Institute, Rice Fact Sheet, Bacterial Leaf Streak.

Annonymous. 2007. Xanthomonas oryzae: Diagnost. Pathol., 37(3): 543-553.

Annonymous. 2010. International Rice Research Institute, Rice Fact Sheet, Bacterial Blight. March 2010.

Annonymous. 2016. Foreign Agricultural Service / Office of Global Analysis. International Production. Assessment Division (IPAD / PECAD. USDA, World Agricultural Production (May 2016. Ag Box 1051, Room 4630, South Building. Washington, DC 20250-1051. p-19.

Ardales, E.Y., Leung, H., Vera Cruz, C.M., Mew, T.W., Leach, J.E. and Nelson, R.J. 1996. Hierarchical analysis of 
spatial variation of the bacterial blight pathogen across diverse agroecosystems in the Philippines. Phytopathol., 86: 241-252.

Benedict, A.A., Alvarez, A.M., Berestecky, J., Imanaka, W., Mizumoto, C.Y., Pollard, L.W., Mew, T.W. and Gonzalez, C.F. 1989. Pathovar-specific monoclonal antibodies for Xanthomonas campestris pv. oryzae and for Xanthomonas campestris pv. oryzicola. Phytopathol., 79: 322-328.

Chand, T., Singh, N., Singh, H. and Thind, B.S. 1979. Field efficacy of stable bleaching powder to control bacterial blight of rice. Intern. Rice Res. Newsl., 4(4): 12.

Cottyn, B., Cerez, M.T. and Mew, T.W. 1994. Chapter 7: Bacteria. In: A Manual of Rice Seed Health Testing. Mew, T.W. and Mistra J.K. eds.. IRRI, Manila (PH), pp. 322-328.

Fukunaga, K. 1966. Antibiotios and new fungicides for control of rice diseases.Proc. Symposium on Plant Diseases in the Pacific. XI Pacific Science Congress, Tokyo.pp170-180.

Furutani, A., Takaoka, M., Sanada, H., Noguchi, Y., Oku, T., Tsuno, K., Ochiai, H. and Tsuge, S. 2009. Identification of novel type III secretion effectors in Xanthomonas oryzae pv.oryzae. Mol. Plant-Microbe Interact, 22(1): 96-106.

Gnanamanickam, S.S., Alvarez, A.M., Benedict, A.A., Sakthivel, N. and Leach, J.E. 1993. Characterization of weakly virulent bacterial strains associated with the bacterial blight (BB) or leaf streak (BLS) in southern India. Intern. Rice Res. Inst. Newsl., 18: 5-16.

Gnanamanickam, S.S., Sakthivel, N., Nelson, R., Alvarez, A.M. and Leach, J.E. 1995. In: Detection of Plant Pathogens and their Management.Verma, J.P., Varma, A. and Kumar, D. eds. Anchor Publ. P)
Ltd., New Delhi, pp. 159-172.

Hopkins, C.M., White, F.F., Choi, S.H., Guo, A. and Leach, J.E. 1992. Identification of a family of avirulence genes from Xanthomonas oryzae pv. oryzae. Mol. Plant-Microbe Interact, 5: 451-459.

Horino, O. 1984. Ultra structure of water pores in Leersia japonica Mikino and Oryza sativa L. its correlation with the resistance to hydrathodal invasion of Xanthomonas campestris pv. oryzae. Ann. Phytopath. Soc. Japan. 50: 72-76.

Ishiyama, S. 1922. Studies on the white leaf disease of rice plants, Rep. Agric. Expt. Sin. Tokyo. 45: 233-251.

Kauffman, H.E., Reddy, A.P.K., Hsieh, S.P.Y. and Merca, S.D. 1973. An improved technique for evaluating resistance of rice varieties to Xanthomonas oryzae pv. oryzae. Plant Dis. Rep., 57: 537-541.

Kelemu, S. and Leach, J.E. 1990. Cloning and characterization of an avirulence gene from Xanthomonas campestris pv. oryzae. Mol. Plant-Microbe Interact. 3: 59-65.

Kiryu, T., Nishizawa, T. and Kuhara, S. 1954. On the relation of time passing after injuring of rice plant leaves to the infection of bacterium Xanthomonas oryzae. Bull.Kyushu Agric. Expt. Stn. 2: 125-129.

Leach, J.E., Leung, H., Nelson, R.J. and Mew, T.W. 1995. Population biology of Xanthomonas oryzae pv. oryzae and approaches to its control. Curr. Opin. Biotechnol., 6(3): 298-304.

Leach, J.E., Rhoads, M.L., Vera Cruz, C.M., White, F.F., Mew, T.W. and Leung, H. 1992. Assessment of genetic diversity and population structure of Xantnomones oryzae pv. oryzae with a repetitive DNA element. Appl. Environ. Microbial., 58: 2188-2195.

Leach, J.E., White, F.F., Rhoads, M.L. and Leung, H. 1990. A repetitive DNA 
sequence differentiates Xanthomonas campestris pv. oryzae from other pathovars of $X$. campestris. Mol. PlantMicrobe Interact. 3: 238-246.

Mew, T.W., Alvarez, A.M., Leach, J.E. and Swings, T. 1993. Focus on bacterial blight of rice. Plant Dis. 77: 5-12.

Mew, T.W., Mew, I.C. and Huang, J.S. 1984. Scanning electron microscopy of virulent and avirulent strains of Xanthomonas campestris pv. oryzae on rice leaves. Phytopathol., 74: 635-641.

Nakagami, K., Tanaka, H., lshida, M. and Koremura, M. 1980a. Greenhouse evaluation of techlofthalam as a rice bacterial leaf blight control agent. $J$. Pestic. Sci., 5: 237-242.

Nakagami, K., Tanaka, H., Yamaoka, K. and Tsujino, Y. 1980b. Population of Xanthomonas oryzae and concentration of techlofthalam in guttation droplets on rice leaf sprayed with techlofthalam. $J$. Pestic. Sci., 5: 607-609.

Nelson, R.J., Baraoidan, M.R., Vera Cruz, C.M., Yap, I.V., Leach, J.E., Mew, T.W. and Leung, H. 1994. Relationship between phylogeny and pathotype for the bacterial blight pathogen of rice. Appl. Environ. Microbiol., 60: 32753283.

Ou, S.H. 1985. Rice diseases. $2^{\text {nd }}$ ed. Commonwealth Mycological Institute, Kew, UK. pp. 109-201.

Mew, T.W. 1987. Current status and future prospects of research on bacterial blight of rice. Ann. Rev. Phytopathol., 25: 359382.

Mew, T.W. 1992. Bacterial blight. In: Compendium of rice diseases. Webster, R.K. and Pamela, S.G. eds.. St. Paul: Amer. Phytopathol. Soc., pp. 10-11.

Mew, T.W., Vera Cruz, C.M., Reyes, R.C. and Zaragoza, B.A. 1979. Study on kresek (wilt) of the rice bacterial blight syndrome. IRRI. Res. Pap. Ser. 39: 1-8.

Mizukami, T. and Wakimoto, S. 1969.
Epidemiology and control of bacterial leaf blight of rice. Ann. Rev. Phytopathol., 7: 51-72.

Murty, V.S.T. and Devadath, S. 1984. Role of seed in survival and transmission of Xanthomonas campestris pv. oryzae causing bacterial blight of rice. Phytopathol., 110: 15-19.

Nino-Liu, D.O., Ronald, P.C. and Bogdanove, A.J. 2005. A Simple method of mass inoculation of rice effective for both pathovars of Xanthomonas oryzae, and the construction of comparable sets of host cDNA libraries spanning early stages of bacterial leaf blight and bacterial leaf streak. J. Phytopathol., 153: 500-504.

Niño-Liu, D.O., Darnielle, L. and Bogdanove, A.J. 2006. Xanthomonas oryzae pathovars: model pathogens of a model crop. Mol. Plant Pathol. 7(5): 303-324.

Premalatha Dath, A. and Devadath, S. 1983. Role of inoculum in irrigation water and soil in the incidence of bacterial blight of rice. Indian Phytopathol., 36: 142144.

Reddy, M.T.S. and Reddy, A.P.K. 1990. Variability in Xanthomonas campestris pv. oryzae and their relationship to physiological characters. Ann. Agric. Res., 11: 283-290.

Seki, M. and Mizukami, T. 1956. Application of antibiotics against bacterial leaf blight of rice plant [in Japanese]. Kyushu Agric. Res., 17: 98.

Sulaiman, M. and Ahmed, L. 1965. Controlling bacterial blight of paddy in Maharashtra. Indian Farming, 15(8): 27-29, 34.

Swings, J., Van den Mooter, M., Vauterin, L., Hoste, B., Gillis, M., Mew, T.W. and Kersters, K. 1990. Reclassification of the causal agents of bacterial blight (Xanthomonas campestris pv. oryzae.) and bacterial leaf streak (Xanthomonas campestris pv. oryzae) of rice as 
pathovars of Xanthomonas oryzae (ex Ishiyama, 1922) sp. nov., nom. rev. Intern. J. Syst. Bacteriol. 40: 309-311.

Tagami, Y. and Mizukami, T. 1962. Historical review of the researches on bacterial blight of rice caused by Xanthomonas oryzae (Uyede and Ishiyama) Dowson. Spec. Rep. Plant Dis. Ins. Pests Forecasting Serv. 10. Kyushu Agric. Station, Japan, p. 112.

Tagami, Y., Kuhara, S., Kurita, T., Fujii, H., Sekiya, N., Yoshimura, S., Sato, T. and Watanabe, B. 1963. Epidemiological studies on the bacterial blight of rice: overwintering of the pathogen. Bull. Kyushu Natl. Agric. Expt. Stn. 9: 89122.

Takahi, Y. 1985. Shirahagen R-S (tecloftalam. Japan. Pesti. Inf. 46: 2530.

Tu, J., Ona, I., Zhang, Q., Mew, T.W., Khush, G.S. and Datta, S.K. 1998.Transgenic rice variety $I R 72$ with $\mathrm{Xa}-21$ is resistant to bacterial blight. Theor. Appl. Genet. 97: 31-36.

Unnamalai, M., Mew, T.W. and
Gnanamanickam, S.S. 1988. Sensitive methods for detection of Xanthomonas campestris pv. oryzae in rice seeds. In: Adv. Res. Plant Pathogenic Bacteria. Gnanamanickam, S.S. and Mahadevan, A. eds. Today \& Tomorrow Printers, New Delhi, pp. 73-82.

Wang, G.L., Song, W.Y., Ruan, D.L., Sideris, S. and Ronald, P.C. 1996. The cloned gene $\mathrm{Xa21}$, confers resistance to multiple Xanthomonas oryzae pv. oryzae isolates in transgenic plants. Mol. Plant Microbe Interact, 9: 850855.

Yashitola, J., Krishnaveni, D., Reddy, A.P.K. and Sonti, R.V. 1997. Genetic diversity within the population of Xanthomonas oryzae pv. oryzae in India. Phytopathol., 87: 760-765.

Zhang, S., Song, W.Y., Chen, L., Ruan, D.L., Taylor, N., Ronald, P.C., Beachy, R. and Fauquet, C. 1998. Transgenic elite indica rice varieties, resistance to Xanthomonas oryzae pv. oryzae. Mol. Breed, 4: 551-558.

\section{How to cite this article:}

Pranamika Sharma, L.C. Bora, K.C. Puzari, A.M. Baruah, R. Baruah, K. Talukdar, L. Kataky and Phukan, A.. 2017. Review on Bacterial Blight of rice caused by Xanthomonas oryzae pv. oryzae: different management approaches and role of Pseudomonas fluorescens as a potential biocontrol agent. Int.J.Curr.Microbiol.App.Sci. 6(3): 982-1005. doi: https://doi.org/10.20546/ijcmas.2017.603.117 